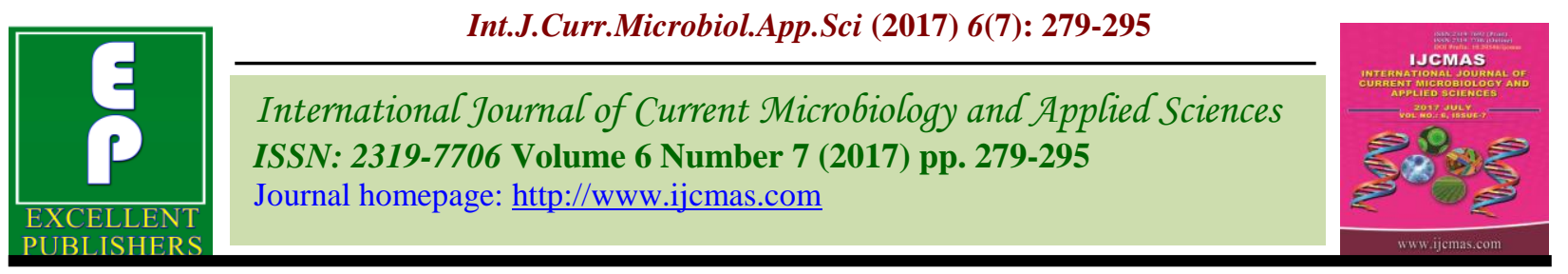

Original Research Article

https://doi.org/10.20546/ijcmas.2017.607.033

\title{
Alternate Land Use Options for Livelihood Security of the Farmers - A Case Study of Chhata tehsil, Mathura District, Uttar Pradesh, India
}

\author{
Ashok Kumar ${ }^{1 *}$, S.K. Mahapatra ${ }^{1}$, Tarsem Lal ${ }^{1}$, R.P. Yadav ${ }^{1}$ and S.K. Singh ${ }^{2}$ \\ ${ }^{1}$ ICAR-National Bureau of Soil Survey and Land Use Planning (NBSS \& LUP) Regional Centre, \\ IARI Campus, PUSA, New Delhi-110012, India \\ ${ }^{2}$ ICAR-National Bureau of Soil Survey and Land Use Planning (NBSS \& LUP), \\ Nagpur- 440033, India \\ *Corresponding author
}

A B S T R A C T

Farm household socio-economic survey was carried out using stratified random sampling technique in Chhata tehsil of Mathura district, Uttar Pradesh, India to develop alternate

Keywords

Soil series,

Benefit-cost ratio,

Sustainability

yield index,

Alternate land use

options,

Livelihood

security.

Article Info

Accepted:

04 June 2017

Available Online:

10 July 2017 land use options for livelihood security of the farmers. The information shared by the respondent farmers $(n=140)$ on range of issues pertaining to agriculture, bio-physical and socio-economic constraints and potential of the area covered 8 dominant soil series viz., Simri, Garhsauli, Tarauli, Chhatikara, Chhata, Ladpur, Neri and Bechhawan Bihari. The occupational structure (includes whole farm households besides the respondent farmers) revealed that about $68 \%$ of the male $(n=178)$ engaged in farming while, only $31 \%$ females $(\mathrm{n}=147)$ had participation in various economic activities besides household responsibilities. Since, crops and cropping pattern registered a decline in number of crops grown in 1970s to 2010 with predominance of rice-wheat cropping system. The crops were assessed in terms of benefit-cost ratio (B: C Ratio) and sustainability yield index (SYI) indicated highest B: C ratio for mustard crop (3.87) in Simri soil series while, SYI for rice (0.80) in Chhata series. Beside crops, livestock also supported the livelihood of farm households. Tarauli soil series recorded highest net monthly income (INR, 1917). Alternate land use options for livelihood improvement of the farmers based on integration of all the information resulted in several land use options viz., rice (1.86), cotton (2.04), pearl millet (1.41) during Kharif season while, mustard (2.98), wheat (2.20), sugarcane (2.07) in Rabi season (crops)+ animal husbandry+ horticulture/ crops+ animal husbandry+ farm forestry.

\section{Introduction}

India accounts for $2.4 \%$ of the global land area and supports nearly $17 \%$ of the world's population. Agriculture is the main stay of majority of the population, as it engaged 118.7 million cultivators and accounts for about $54.6 \%$ of total employment (The Census of India 2011). The share of agriculture and allied sectors in total Gross Domestic Product (GDP) during 2014-15 was $18 \%$, while the share of crops and livestock in total GDP was 11.8 and $3.9 \%$, respectively. Agriculture system in India is predominantly mixed farming (crops and livestock) type, of which livestock is considered as an important secondary source of income for 70 million rural households engaged in it (The Economic Survey, 2015). Realizing the importance of agriculture in 
livelihood security of farming community, it becomes imperative to highlight the factors which affect the agriculture and in turn livelihood. The most notable factors which govern agriculture and livelihood are natural (soil, water and climate) and socio-economic in nature. Climate plays a pivotal role in determining the crops and cropping patterns of a particular area and hence, stability of crop production and food supply as well as livelihood of millions of farmers. Among the natural resources, importance of soil is increasing day-by-day on account of shrinking land holding size and its various kinds of degradation. (Geist and Lambin, 2004; Reynolds et al., 2007; Safriel et al., 2005; Safriel and Adeel, 2008) reported some typical and common mechanisms which establish vulnerability of smallholder farmers in developing countries that are characterized by increasing pressures on natural resources, soil degradation and breakdown of traditional coping mechanisms, which in turn posed barriers to alternative livelihoods.

Beside soil and climatic factors, socioeconomic aspects are of utmost importance to develop land use options for the farming community. India has majority of the holdings under marginal and small landholders categories and that too is uneconomical due to several reasons such as uncertainty of income, rising input costs, high variability in yields besides low output prices. Such low level of income from these holdings leads to some fatal social consequences like rising incidence of farmers' suicides in various parts of the country (Mishra, 2008). Therefore, it is essential to enhance the income level of small land holders and landless agricultural labourers through additional livelihood opportunities i.e. by diversifying farm and non-farm occupations (Walingo et al., 2009). Gender based differences in income generating activities in rural farming households is another social issue. Women, however, play a significant role in economic activities but got less recognition as compared to their male counterparts. Chen (1989) suggested gender neutral strategies to ensure equal participation of females in economic activities particularly in livelihood securing activities. Illiteracy, high incidence of poverty, decrease in land availability and overpopulation are the other socio-economic factors associated with changes in agriculture system and livelihoods pattern.

The issue of livelihood security has been a question of relevance for the planners, policy makers and researchers. Therefore, it is imperative to develop most suitable land use options for agriculture for livelihood security of the millions of small and marginal farmers' world over. Taking the issue of livelihood security at centre stage an attempt was made in this study to address this question with the development of alternate land use options for different soil series of the study area.

\section{Materials and Methods}

\section{Location of the study area}

The Chhata tehsil of Mathura district, Uttar Pradesh, India is situated between $27^{\circ} 33^{\prime}$ to $27^{\circ} 56^{\prime} \mathrm{N}$ latitude and $77^{\circ} 17^{\prime}$ to $77^{\circ} 42^{\prime} \mathrm{E}$ longitudes (Fig.1), surrounded by Faridabad district of Haryana in the north, River Yamuna in the east, tehsil Mathura in the south and district Bharatpur of Rajasthan in the west. It occupies a total area of 1063.5 $\mathrm{km}^{2}$ with a population of 569021 (The Census of India, 2011) and consists of three blocks namely Chhata, Nandgaon and Chaumuha.

\section{Physiography and soil resources}

The study area mainly comes under Yamuna River alluvium, which is continuous and conformable series of fluvial and alluvial deposits. It is mainly composed of 
unconsolidated beds of sand, silt and clay as well as their mixture in varying proportions, besides it also has some portion under hillocks of Aravalli Mountains. The area has four physiographic regions viz., active flood plains, recent alluvial plains, old alluvial plains and Aravalli hills, which further subdivided into 10 physiographic units based on slopes and elevations. Soil resources of Mathura district were characterized and classified for land use planning (Mahapatra et al., 2010, 2013).

Majority of the soils occur on very gently sloping to nearly level meandering plains of old alluvial origin and mainly belongs to Inceptisols and Entisols orders. Salinity/sodicity and water logging also poses serious problems to crop production. Kumar et al., (2015) reported nine soil series (Simri, Garhsauli, Tarauli, Chhatikara, Chhata, Ladpur, Neri, Bechhawan Bihari and Barsana) in the study area. The soils suitability for crops was evaluated based on FAO land evaluation procedure (FAO, 1976).

\section{Climate profile of study locale}

The climate of the area is semi-arid, characterized by a hot dry summer and very cold winter. The mean annual temperature is $26^{\circ} \mathrm{C}$ (Fig. 2) while, average annual rainfall is $558 \mathrm{~mm}$, of which nearly 80 percent is received during the months of June to September.

\section{Survey methodology}

Under this study a household socio-economic survey was carried out to collect socioeconomic data of the farming community in 14 villages of 8 dominant soil series of the study area. Although, study area have nine soil series (Kumar et al., 2015) but one series (Barsana) was deliberately left during survey due to its rocky nature and negligible area.
The socio-economic information was collected in a comprehensive questionnaire cum proforma using stratified random sampling technique. A total of 140 respondent farmers were selected from the marginal, small, medium and large land holding categories including 14 randomly selected landless labourers, agricultural labourers and daily paid workers with a view to assess their livelihood earning activities in rural set up.

\section{Statistical analysis}

The survey data were analyzed for mean, range and standard deviation using micro-soft excel software. B: $\mathrm{C}$ ratio and sustainability yield index were calculated with the formula given as under-

\section{Sustainability yield index (SYI)}

Three year yield data for different crops were collected from the respondent farmers to assess SYI. The index was calculated using the formula suggested by Singh et al., (1990).

SYI $=\frac{\text { Mean Yield }- \text { Standard Deviation }}{\text { Maximum Yield }}$

The range of 'Sustainability Index' varies from -1 to +1 . Any practice yielding SI greater than 0.66 is considered as a recommendable component for production of a crop in a region and SI of 0.50 to 0.65 is considered as highly promising, while a practice with SI less than 0.33 is undependable (Vittal et al., 2002).

\section{Benefit-cost ratio ( $\mathrm{B}: \mathrm{C}$ ratio)}

B: C Ratio for different crops was calculated to assess their economic viability as an alternate option using the following formula-

$\mathrm{B}: \mathrm{C}$ ratio $=\frac{\text { Gross return }}{\text { Cost of cultivation }}$ 


\section{Development of alternate land use options}

The land use options for livelihood security were developed based on integration of socioeconomic, bio-physical (soils and crops) and other natural resource base information of the area (Climate, rainfall, temperature etc.).

The constraints and potentials of natural biophysical resources (crops and cropping pattern, soil, water and climate) were identified and assessed in terms of their influence on crop yield, livestock resources and livelihood of the farmers. Beside soil suitability, major crops were evaluated in terms of B: C ratio and SYI in order to arrive at the economic viability and sustainability of various soil series for developing the alternate land use options.

\section{Results and Discussion}

Social profile of the respondent farming households

\section{Age group and engagement in farming} activities

Survey results depicted in figure 3 highlight the decline in share of young age (25-35 years) respondents in farming activities while, maximum involvement $(36 \%)$ of above 55 years age (mainly due to their traditional legacy of farming occupation).

\section{Literacy profile of the respondent farmers}

The survey results of the respondent farmers $(n=140)$ revealed that highest percentage of literate respondents belongs to Ladpur soil series $(78 \%)$, while lowest in Chhata series $(62 \%)$. In literates, the share of senior secondary educated respondents was higher (25.18\%) followed by primary level literates $(24.31 \%)$.
However, variation in literacy level was also observed within and between soils series but less in comparison to illiterate respondents (Fig. 4).

\section{Economic profile (occupational set up)}

\section{Gender involvement in economic activities}

Total number of respondents $(\mathrm{n}=140)$ shared their information during survey but other members of the farm family were also included for occupational structure. Results of their data analysis revealed that about $68 \%$ of the male $(n=178)$ engaged in farming followed by farmers + agriculture labourer $(13 \%)$ while, only $31 \%$ females $(n=147)$ had participation in various economic activities besides household responsibilities (Fig. 5 ab).

The figure highlighted the differences in occupations for both the genders, which indicated that woman had contributed more towards high level of unpaid labour in households as well as agriculture activities. However, among the economic activities, farming sector had key role in providing employment opportunities for the females.

\section{Livestock as a contributor in livelihood security}

Livestock is an integral part of agriculture and plays an important role in livelihood security of the farmers as well as landless labourers. It was observed that total monthly earning from individual milch animal was highest in Tarauli soil series (INR. 5013) followed by Simri series (INR. 4420) and least in Ladpur series (INR. 2877). Net monthly earning from livestock in the study area ranged from INR. 891 to 1917 , while mean net monthly earning from livestock for the surveyed villages of different soil series was INR.1439.5 (Table 1). 
Appraisal of crops and cropping pattern for viable livelihood options

Livelihood in rural parts of the study area was largely constructed on agriculture. Therefore, study of changes in crops and cropping pattern for land use options for livelihood security becomes imperative. The information shared by the respondent farmers revealed the decline in number of crops during the rememberable period of 1970 to 2010 (Fig. 6). In Simri series of Chhata tehsil rice-wheat was the dominant cropping systems but with diverse cropping pattern including pulses, oilseeds and fodder crops. Cropping pattern in Chhata soil series was largely consisted of cereals, pulses and sugar crops during 1970s but in the last two decades rice-wheat cropping system became dominant. Among the crops wheat occupied highest area $(52.32 \%)$ followed by rice $(24.81 \%)$, mustard $(8.17 \%)$, indicated the dominance of ricewheat cropping system. However, mustard, cotton, pigeon pea, sugarcane, potato and cluster beans were also grown successfully. Beside crops, vegetable and fruit crops were also cultivated on a very small scale in the study area.

\section{Assessment of crop yield, sustainability and economic viability for livelihood option}

The average values of yields, SYI and B: C ratio of different crops grown in major soil series of Chhata tehsil (Table 2) revealed that highest rice yield (62.5 q/ha) was observed in Garhsauli soil series, while least in Tarauli and Chhata series (52.5 q/ha each). Highest B: $\mathrm{C}$ ratio (2.33) for wheat was observed in Bechhawan Bihari series and SYI in Tarauli soil series (0.89). In case of mustard, highest yield (22.5 q/ha), B: C ratio and SYI values were recorded in Simri series. Pearl millet yield in different soil series ranged from 15 to $27.5 \mathrm{q} / \mathrm{ha}$. Cotton recorded high yield $(22.5$ q/ha), B: C ratio and SYI in Simri series (2.39 and 0.58). Sugarcane yield was highest
(768.75) in Chhata soil series while, B: C ratio (2.12) in Simri series and SYI in Garhsauli series (0.85). The higher values of yield and $\mathrm{B}$ : $\mathrm{C}$ ratio indicated the high return from the crops grown, while high values of SYI indicated that the component crop or cropping pattern is recommendable for the region. Both the indices were observed to be high in the results of survey data and hence, the values were taken to suggest the alternate land use options from the crops to ensure livelihood improvement through farming.

\section{Alternate land use options for livelihood security}

The issue of livelihood of millions of farmers could rightly be addressed by developing and adopting appropriate alternate options based on yield, SYI and B: C ratio (in case of crop options). While, other options like animal husbandry, horticulture (vegetables and fruits) and agro-forestry (farm forestry) options were developed based on soil and climatic suitability evaluation as well as availability of market. The alternate land use options for different soil series were categorized as crop based, horticulture based, agroforestry based and animal husbandry based (Table 3).

The results of economic analysis and sustainability indices for major soils of the study area indicated that the developed land use options were economically viable and sustainable for livelihood security for the farming community. The alternate land use options for livelihood improvement in Chhata tehsil includes rice (1.86), cotton (2.04), pearl millet (1.41) during Kharif season while, mustard (2.98), wheat (2.20), sugarcane (2.07) in Rabi season (crops)+ animal husbandry+ horticulture/ crops+ animal husbandry+ farm forestry (Tables 2 and 3 ).

The declining share of young age (25-35 years) respondents in farming activities indicated better job opportunities with 
comfort and higher income in the nearby areas of Mathura district (urban area) and National Capital Region (NCR).

Youngsters prefer jobs in government and private sector followed by engagements in other non-farming activities (business). Similar observations for age and job opportunities were reported by Uma et al., (2013). Survey results of 140 respondent farmers revealed that the share of senior secondary educated respondents were higher (25.18\%) followed by primary level literates $(24.31 \%)$ among the literacy categories recorded for the farming households. The respondents educated above secondary level were least engaged in farming occupation, rather they choose to be in other professions. Relationship between literacy level and job opportunities was also reported by Uma et al.,
(2013). More involvement of persons above the age of 55 years in agriculture was largely due to their traditional attachment to farming occupation and as a matter of legacy. Farming was major occupation for males while, majority of the female were housewives. However, women also participated in most of the farm work viz., field preparation, sowing, weeding, harvesting and threshing activities. Chen (1989) also reported the involvement of women in almost all sort of agriculture activities which can be performed by men. Among the economic activities farming was played a key role in engaging the females $(31 \%)$ of study area for their family livelihood support besides household responsibilities. It indicated the less employment of rural women in non-farm activities. Participation rate of women in non-farm employment is low as compare to the men (Haggblade et al., 1989).

Table.1 Monthly earning (INR.) from livestock in different soil series of Chhata tehsil

\begin{tabular}{|c|c|c|c|c|c|}
\hline Series & $\begin{array}{c}\text { Average } \\
\text { monthly } \\
\text { expenditure/mi } \\
\text { lch animal }\end{array}$ & $\begin{array}{c}\text { Average } \\
\text { monthly } \\
\text { expenditure/ } \\
\text { dry animal }\end{array}$ & $\begin{array}{l}\text { Average total } \\
\text { monthly } \\
\text { earning/milch } \\
\text { animal }\end{array}$ & $\begin{array}{l}\text { Average net } \\
\text { Monthly } \\
\text { earning/mil } \\
\text { ch animal }\end{array}$ & $\begin{array}{l}\text { Average net } \\
\text { Monthly } \\
\text { earning from } \\
\text { livestock* }\end{array}$ \\
\hline Simri & 2027.0 & 1429.0 & 4420.0 & 2393.0 & 1316.0 \\
\hline Garhsauli & 1778.0 & 1500.0 & 4167.0 & 2389.0 & 1682.0 \\
\hline Tarauli & 2000.0 & 1625.0 & 5013.0 & 3013.0 & 1917.0 \\
\hline Neri & 1844.0 & 1500.0 & 4286.0 & 2443.0 & 1661.0 \\
\hline $\begin{array}{l}\text { Chhatikar } \\
\text { a }\end{array}$ & 1714.0 & 1500.0 & 4071.0 & 2357.0 & 1500.0 \\
\hline Chhata & 1876.0 & 1556.0 & 4069.0 & 2193.0 & 1185.0 \\
\hline $\begin{array}{l}\text { Bechhawa } \\
\text { n Bihari }\end{array}$ & 1533.0 & 1250.0 & 3333.0 & 1800.0 & 1364.0 \\
\hline Ladpur & 1431.0 & 1250.0 & 2877.0 & 1445.0 & 891.0 \\
\hline Mean & 1775.4 & 1451.3 & 4029.5 & 2254.1 & 1439.5 \\
\hline STDEV & 210.3 & 136.2 & 657.0 & 466.6 & 322.1 \\
\hline Range & $1431-2027$ & $1250-1625$ & $2877-5013$ & $1445-3013$ & 891-1917 \\
\hline
\end{tabular}


Int.J.Curr.Microbiol.App.Sci (2017) 6(7): 279-295

Table.2 Crop yield (q/ha), B: C ratio and sustainability yield index (SYI) of crops in different soil series of Chhata tehsil

\begin{tabular}{|c|c|c|c|c|c|c|c|}
\hline \multirow[t]{2}{*}{ Soil Series } & \multirow[t]{2}{*}{ Index } & \multicolumn{6}{|c|}{ Crops } \\
\hline & & Rice & Wheat & Mustard & Pearl millet & Cotton & Sugarcane \\
\hline \multirow[t]{3}{*}{ Simri } & Yield & 56.25 & 46.25 & 22.5 & 27.5 & 22.5 & 750 \\
\hline & B: C Ratio & 1.65 & 2.24 & 3.87 & 1.65 & 2.39 & 2.12 \\
\hline & SYI & 0.73 & 0.84 & 0.80 & 0.77 & 0.58 & 0.71 \\
\hline \multirow[t]{3}{*}{ Garhsauli } & Yield & 62.5 & 47.5 & - & - & - & 750 \\
\hline & B: C Ratio & 1.96 & 2.21 & - & - & - & 2.07 \\
\hline & SYI & 0.74 & 0.86 & - & - & - & 0.85 \\
\hline \multirow[t]{3}{*}{ Tarauli } & Yield & 52.5 & 47.5 & 20 & 20 & - & - \\
\hline & B: C Ratio & 1.70 & 2.28 & 3.31 & 1.29 & - & - \\
\hline & SYI & 0.77 & 0.89 & 0.78 & 0.78 & - & - \\
\hline \multirow[t]{3}{*}{ Neri } & Yield & 60 & 48.75 & - & - & - & - \\
\hline & B: C Ratio & 2.05 & 2.32 & - & - & - & - \\
\hline & SYI & 0.74 & 0.84 & - & - & - & - \\
\hline \multirow[t]{3}{*}{ Chhatikara } & Yield & - & 47.5 & 17.5 & 15 & - & - \\
\hline & B: C Ratio & - & 1.80 & 1.99 & 1.11 & - & - \\
\hline & SYI & - & 0.78 & 0.56 & 0.71 & - & - \\
\hline \multirow[t]{3}{*}{ Chhata } & Yield & 52.5 & 49.18 & 16.25 & 22.5 & 15 & 768.75 \\
\hline & B: C Ratio & 1.57 & 2.09 & 2.49 & 1.48 & 1.69 & 2.01 \\
\hline & SYI & 0.80 & 0.84 & 0.69 & 0.80 & 0.50 & 0.80 \\
\hline \multirow[t]{3}{*}{ Bechhawan Bihari } & Yield & 55 & 50 & 20 & 20 & - & - \\
\hline & B: C Ratio & 2.03 & 2.33 & 3.31 & 1.42 & - & - \\
\hline & SYI & 0.69 & 0.79 & 0.78 & 0.70 & - & - \\
\hline \multirow[t]{3}{*}{ Ladpur } & Yield & 60 & 50 & 17.5 & 22.5 & - & - \\
\hline & B: C Ratio & 2.08 & 2.30 & 2.90 & 1.53 & - & - \\
\hline & SYI & 0.74 & 0.85 & 0.71 & 0.72 & - & - \\
\hline \multirow[t]{3}{*}{ Mean } & Yield & 56.98 & 48.33 & 18.95 & 21.25 & 18.75 & 756.25 \\
\hline & B: C Ratio & 1.86 & 2.20 & 2.98 & 1.41 & 2.04 & 2.07 \\
\hline & SYI & 0.74 & 0.84 & 0.72 & 0.75 & 0.54 & 0.79 \\
\hline
\end{tabular}

Crops not grown 
Table.3 Alternate land use options for landscape planning and livelihood security of the farmers in Chhata tehsil

\begin{tabular}{|c|c|c|c|c|c|}
\hline \multirow[t]{2}{*}{ Series } & \multicolumn{2}{|c|}{ Existing cropping pattern/ system } & \multicolumn{3}{|c|}{ Alternate land use options for landscape planning and livelihood security } \\
\hline & Kharif & Rabi & Kharif & Rabi & Other options \\
\hline Simri & $\begin{array}{l}\text { Rice, sorghum, green } \\
\text { gram, black gram }\end{array}$ & $\begin{array}{l}\text { Wheat, } \\
\text { mustard }\end{array}$ & $\begin{array}{l}\text { Cotton, Rice, Pearl } \\
\text { millet, pulses }\end{array}$ & $\begin{array}{l}\text { Mustard, wheat, } \\
\text { sugarcane }\end{array}$ & $\begin{array}{l}\text { Vegetables, fruit crops, } \\
\text { agro- forestry and animal } \\
\text { husbandry }\end{array}$ \\
\hline Garhsauli & Rice, sorghum & $\begin{array}{l}\text { Wheat, } \\
\text { berseem }\end{array}$ & $\begin{array}{l}\text { Rice, maize, pigeon } \\
\text { pea }\end{array}$ & $\begin{array}{l}\text { wheat, sugarcane, } \\
\text { potato, fodder } \\
\text { berseem }\end{array}$ & $\begin{array}{l}\text { Vegetables, fruit crops, } \\
\text { agro- forestry and animal } \\
\text { husbandry }\end{array}$ \\
\hline Tarauli & $\begin{array}{l}\text { Rice, sorghum, Pearl } \\
\text { millet }\end{array}$ & $\begin{array}{l}\text { Wheat, } \\
\text { mustard }\end{array}$ & $\begin{array}{l}\text { Rice, maize, pigeon } \\
\text { pea }\end{array}$ & $\begin{array}{l}\text { Mustard, wheat, } \\
\text { sugarcane, potato }\end{array}$ & $\begin{array}{l}\text { Vegetables, fruit crops and } \\
\text { animal husbandry }\end{array}$ \\
\hline Neri & sorghum, Pearl millet & $\begin{array}{l}\text { Wheat, } \\
\text { sugarcane }\end{array}$ & $\begin{array}{l}\text { Rice, pigeon pea, } \\
\text { maize, pulses }\end{array}$ & $\begin{array}{l}\text { Wheat, mustard, } \\
\text { sugarcane, potato }\end{array}$ & $\begin{array}{l}\text { Vegetables, fruit crops and } \\
\text { animal husbandry }\end{array}$ \\
\hline Chhatikara & Pearl millet, sorghum & $\begin{array}{l}\text { Wheat, } \\
\text { mustard }\end{array}$ & $\begin{array}{l}\text { Pearl millet, pigeon } \\
\text { pea, fodder sorghum }\end{array}$ & $\begin{array}{l}\text { Mustard, wheat, } \\
\text { sugarcane, potato }\end{array}$ & $\begin{array}{l}\text { Vegetables, fruit crops, farm } \\
\text { forestry and animal } \\
\text { husbandry }\end{array}$ \\
\hline Chhata & $\begin{array}{l}\text { Rice, Sorghum, Cotton, } \\
\text { Sesamum, Cluster bean, } \\
\text { Pigeon pea and Sesbania } \\
\text { rostrata }\end{array}$ & $\begin{array}{l}\text { Wheat, } \\
\text { mustard, } \\
\text { berseem }\end{array}$ & $\begin{array}{l}\text { Cotton, Rice, fodder } \\
\text { crops, Cluster bean, } \\
\text { Pearl millet, Pigeon } \\
\text { pea and Sesbania } \\
\text { rostrata }\end{array}$ & $\begin{array}{l}\text { Mustard, wheat, } \\
\text { sugarcane, potato }\end{array}$ & $\begin{array}{l}\text { Vegetables and animal } \\
\text { husbandry }\end{array}$ \\
\hline $\begin{array}{l}\text { Bechhawan } \\
\text { Bihari }\end{array}$ & Rice, Pearl millet & $\begin{array}{l}\text { Wheat, } \\
\text { mustard }\end{array}$ & $\begin{array}{l}\text { Pearl millet, fodder } \\
\text { crops }\end{array}$ & Mustard, wheat, & $\begin{array}{l}\text { Agro-forestry, jujube, citrus, } \\
\text { Vegetables and animal } \\
\text { husbandry }\end{array}$ \\
\hline Ladpur & $\begin{array}{l}\text { Rice, Sorghum, Pearl } \\
\text { millet and Pigeon pea }\end{array}$ & $\begin{array}{l}\text { Wheat, } \\
\text { mustard }\end{array}$ & $\begin{array}{l}\text { Rice, Pearl millet, } \\
\text { maize and Pigeon pea }\end{array}$ & $\begin{array}{l}\text { Mustard, wheat, } \\
\text { sugarcane, potato }\end{array}$ & $\begin{array}{l}\text { Vegetables, fruit crops, } \\
\text { agro- forestry and animal } \\
\text { husbandry }\end{array}$ \\
\hline
\end{tabular}


Fig.1 Location map of surveyed villages of Chhata tehsil of Mathura district (Uttar Pradesh, India)

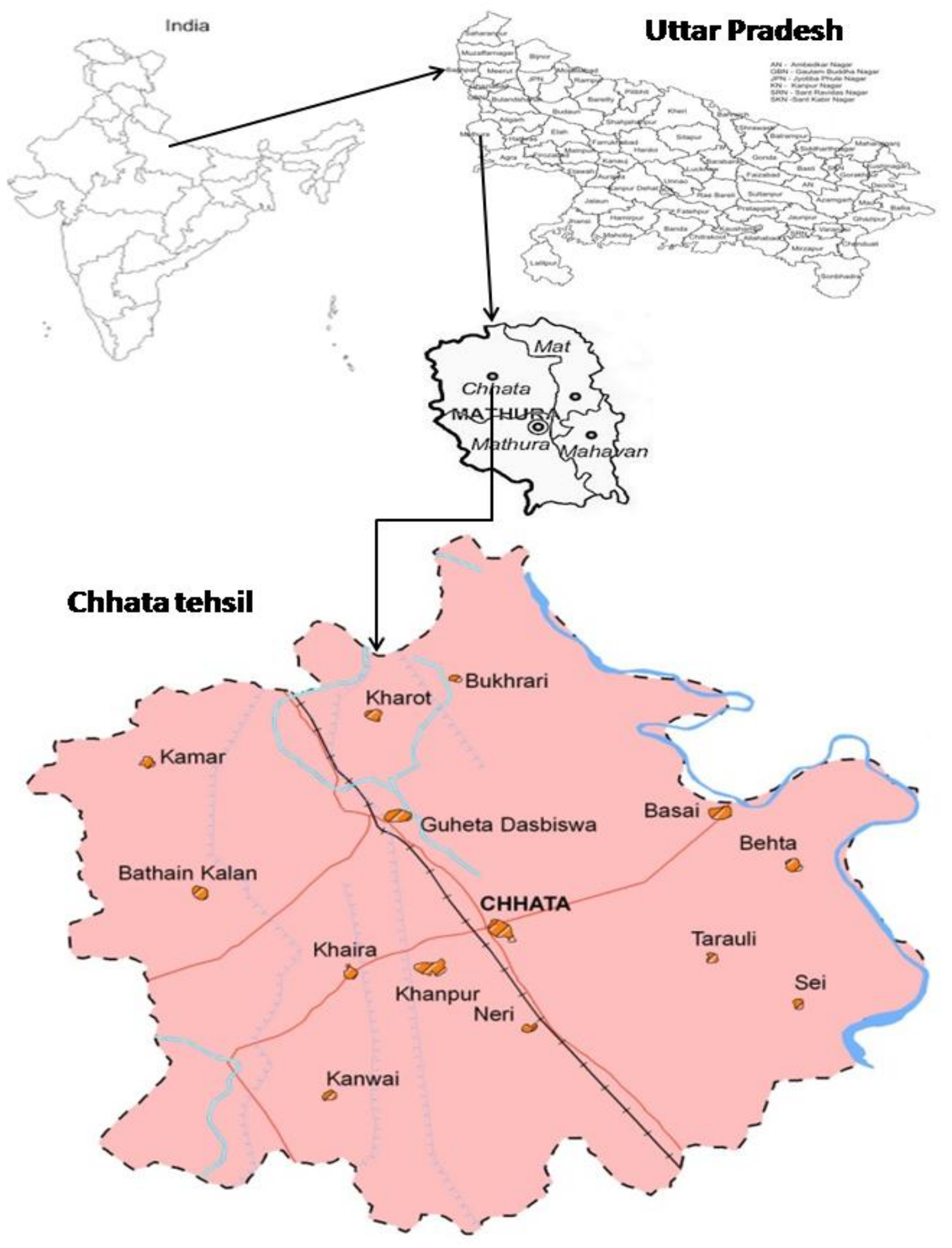


Fig.2 Climate data (1991 - 2000) of the Chhata tehsil (Uttar Pradesh, India)

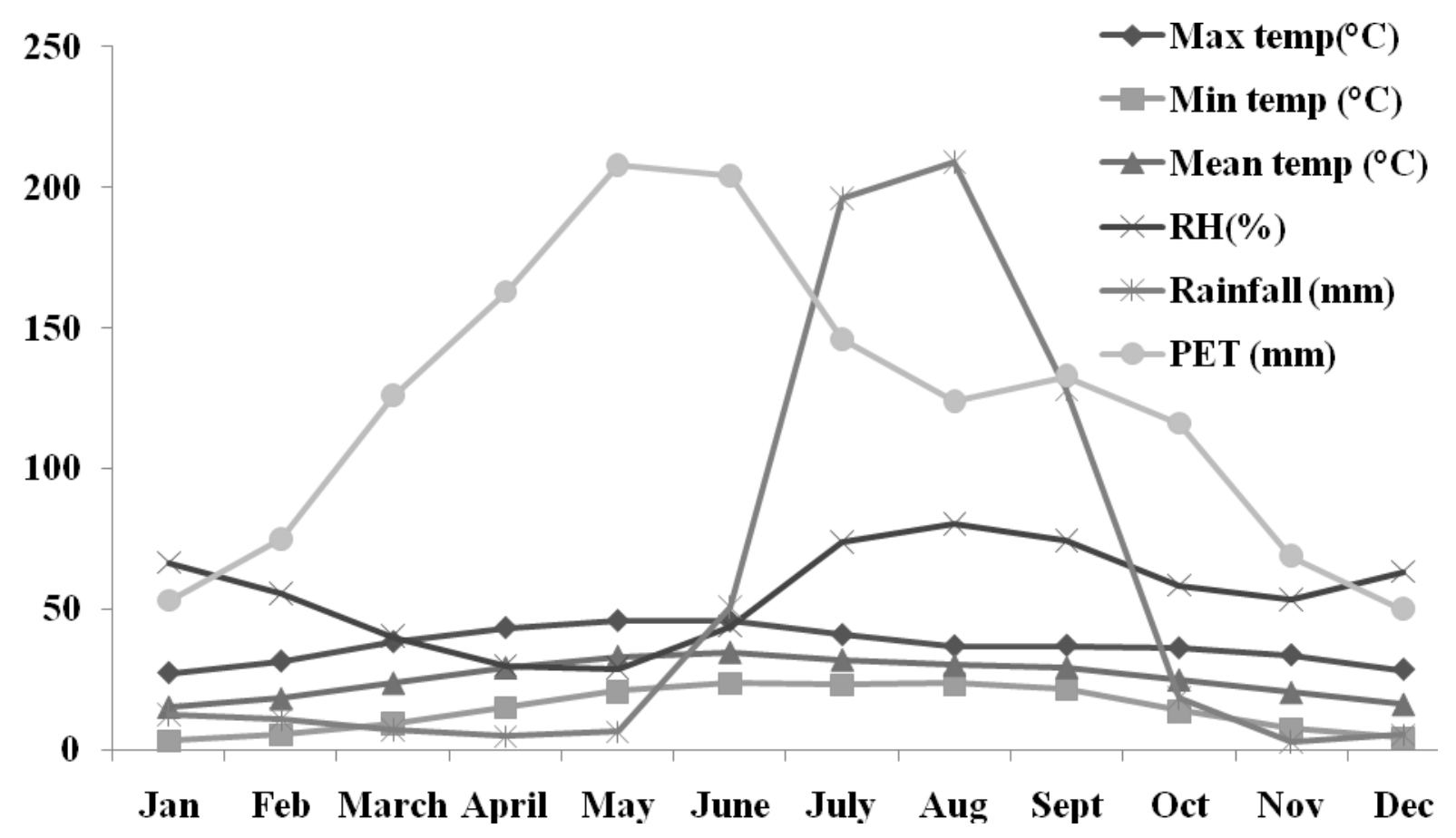

Fig.3 Age group of respondent farmers $(n=140)$ of surveyed villages of Chhata tehsil

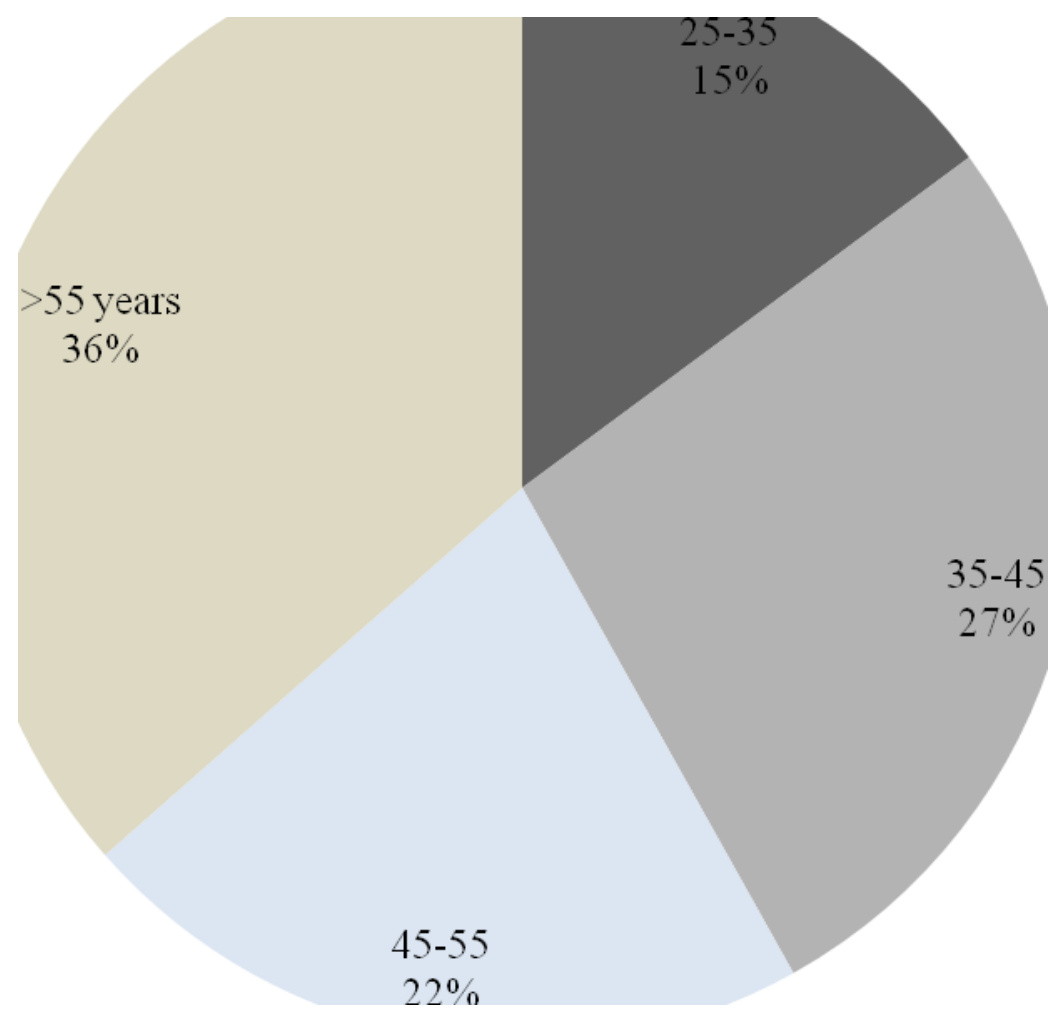


Fig.4 Literacy level (\%) of the respondent farmers $(n=140)$ of The surveyed villages of Chhata tehsil

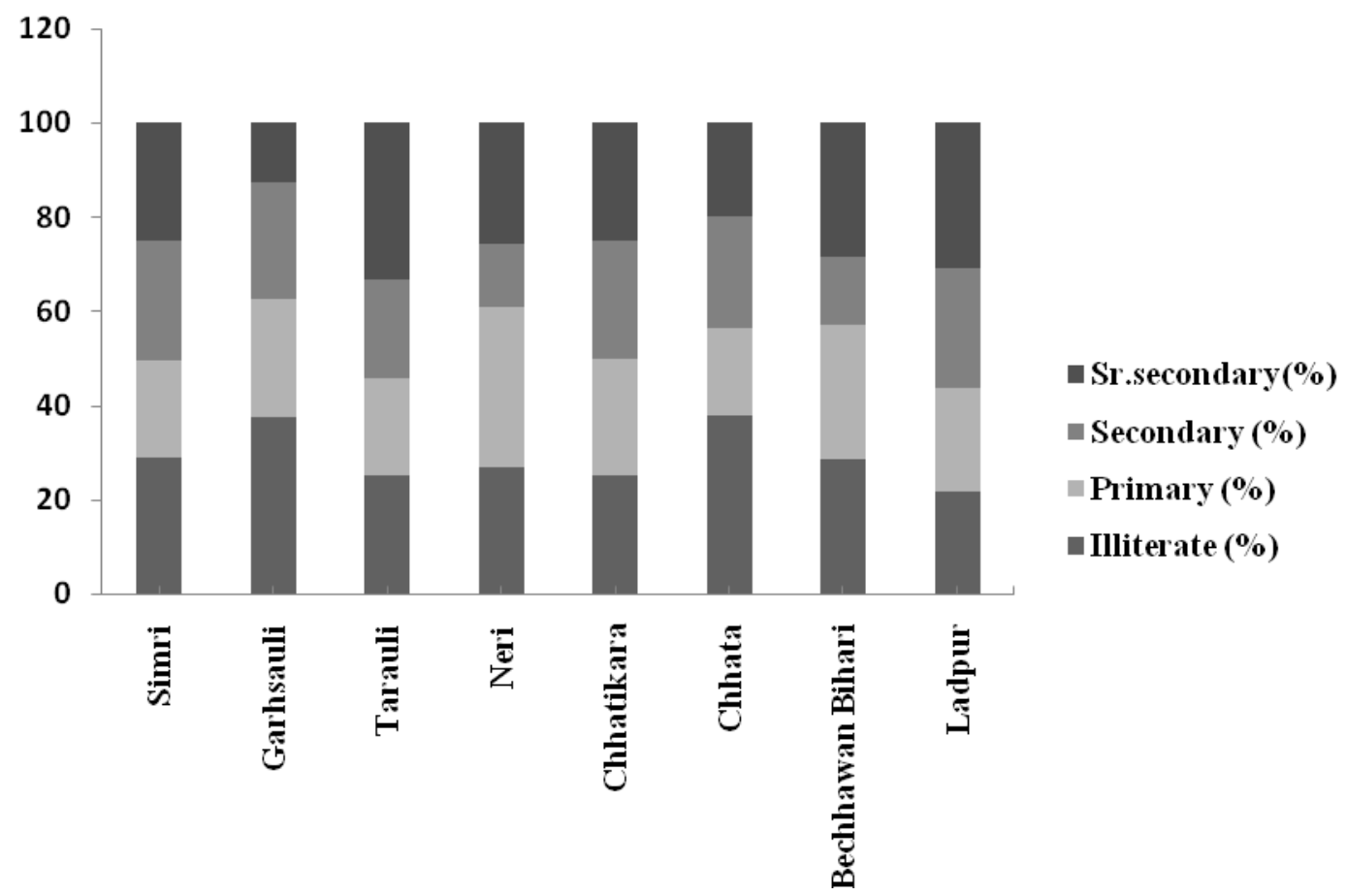

Fig.5 a-b Female ( $n=147$; $a)$ and male $(n=178 ; b)$ population $(\%)$ engaged in economic activities

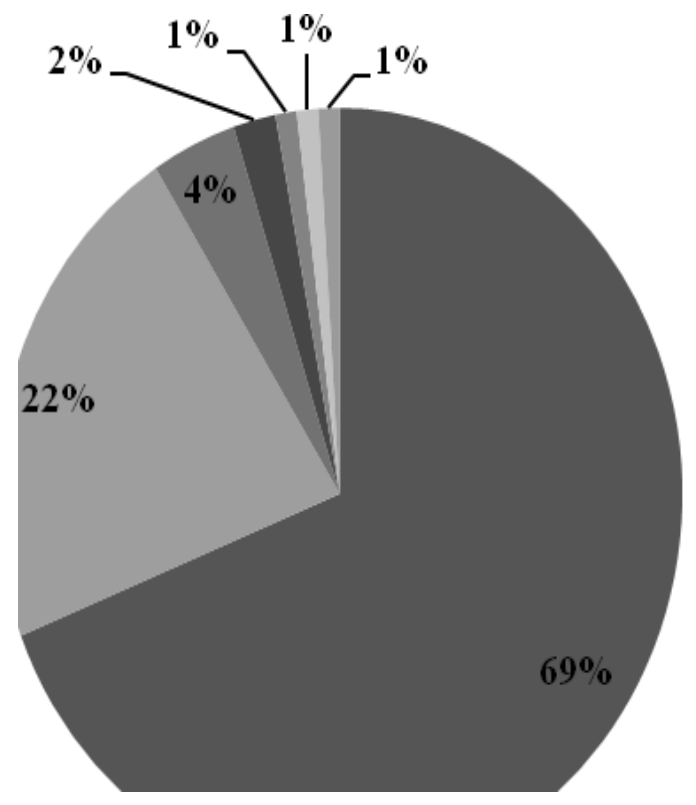

- Housewife

Farming+ Housewife

- Farming+ Agri. Labour

-Farming + Non-Agri.

Labour

- Farming

$\square$ Govt. service

- Privateservice 


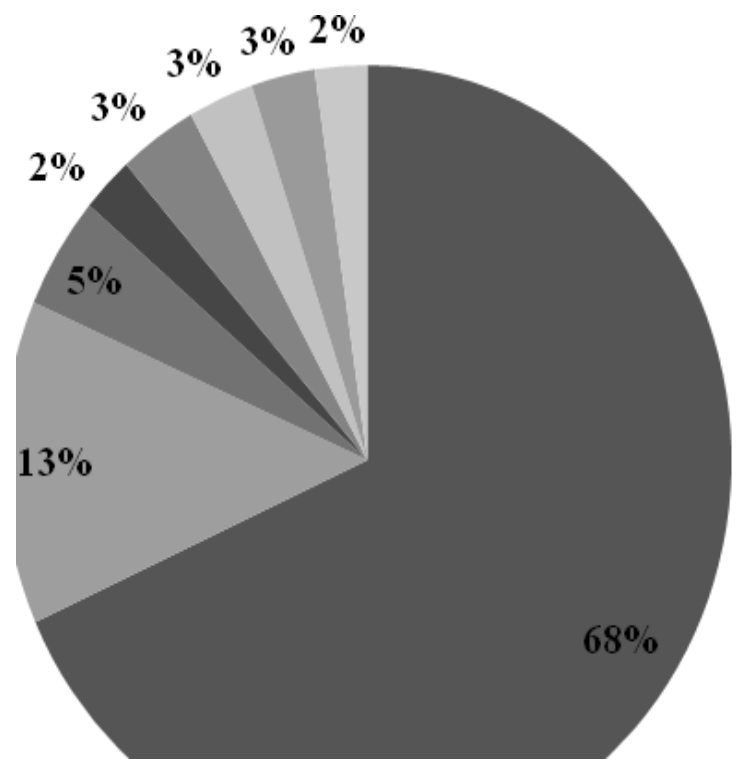

- Farming

- Farming+ Agri. Labour

- Farming+ Non- Agri.

Labour

- Farm labour

- Industrial labour

$\square$ Govt. job

- Privatejob

Business

Fig.6 Temporal changes in cropping patterns in different soil series of Chhata tehsil

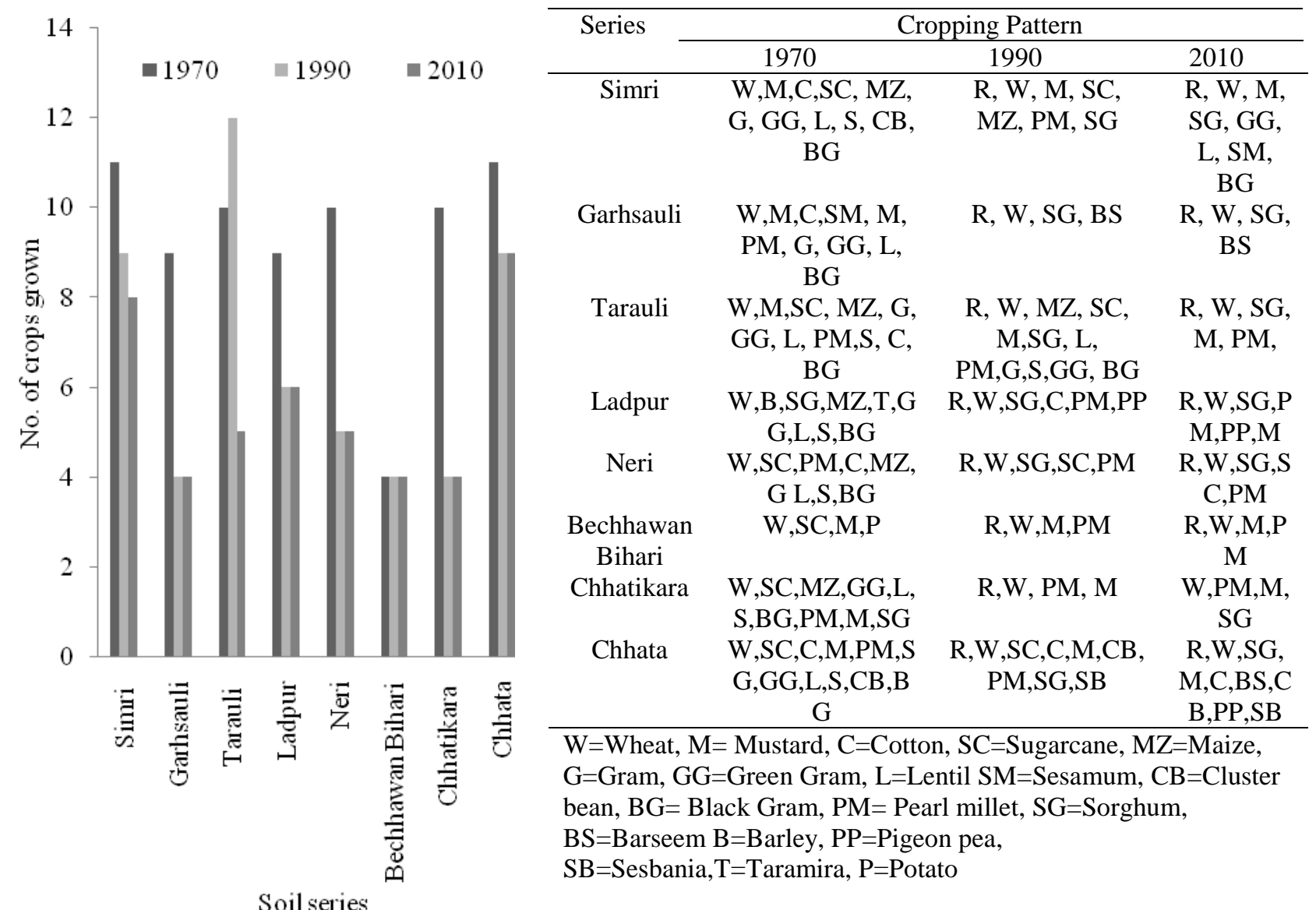


Small and marginal farmers across India earn some extra money from other non-farm activities such as daily paid labourer, as evident from the results that about $13 \%$ males were engaged as farmers + agriculture labourer. Daily casual labour contracts in traditional agriculture or rural economics is important (Sajjad, 1989). Reardon (1997) also recognized the importance of non-farm wage labour vis a vis farm labour. The differences in intra-household occupation revealed that woman had contributed more towards high level of unpaid labour (crop production and livestock) besides domestic chores. Pal (2001) reported that women contributed significantly in agriculture but without any remuneration (unpaid family workers).

Livestock proved a good alternate land use option for diversifying the income (crops and livestocks) of marginal and small farmers as well as landless labourers, as it plays an important role in livelihood security of the farming households by contributing towards net monthly income. Income from livestock varies from one soil series to another on account of varying cost of feed and fodder as well as milk prices. Costales et al., (2007) reported security of livelihood, income, food and nutrition etc. of the rural poor through mixed crop-livestock systems. Agriculture in the study area provides employment opportunities for the major segments of the rural households (Fig. 5a-b) and considered as a key component of livelihood.

Agriculture production is mainly governed by crops and cropping pattern but in recent years a shift was observed in study area from more diverse to less diverse cropping pattern. Farming households in different soil series had varying degrees of changes in cropping pattern during 1970 to 2010. The number of crops registered a decline during the same period according to the experiences shared by the respondent farmers (Fig. 6). In 1970 s, the wheat had predominance in cereals while rice got popular since 1990 largely due to availability of high yielding varieties, improved irrigation facilities and dissemination of technologies under Lab to Land programmes. Mustard was most important cash crop of the region and occupied the status of highly profitable crop. Some other crops grown on small scale include pulses, fodder crops, vegetables and fruit crops. The shift in cropping pattern was largely on account of assured prices, high yield and profits from the major commercial and food grain crops. Although, vegetables and fruit crops cultivated on very small scale, but high demand of these commodities in adjoining cities attracts farmers to grow high value vegetable and fruit crops, indicated the possibilities of rapid change in cropping pattern and land use. The respondent farmers cited various reasons for the change in cropping pattern during the rememberable period, which includes- change in food habits from traditional cereal-pulse to cereals based (wheat and rice), high yield and profitability of some crops (mustard, rice, wheat, cotton, sugarcane) and declining yield of few other crops like pulses. The change in cropping pattern over the period of time is largely due to major factors such as change in food habits, loss of natural resources, low productivity and replacement of traditional cropping system (Semwal et al., 2001). This change in crops and cropping pattern could be addressed through development of alternate land options, which proved to be effective in raising the output and income per unit land area and in turn livelihood security of the farmers. The higher values of Yield, SYI and B: C ratio of rice, wheat and other major crops grown in different soil series of study area was attributed to the availability of assured irrigation with good 
quality water and proper management of crops, provision for adequate drainage and good soil health, improved package of practices, high profit and low production cost of the crops. While, lower values was due to soil limitations, high water table in some areas and non-availability of irrigation water on time due to electricity failure etc. The cotton crop was grown on a very small scale in the study area (Simri and Chhata soil series) and considered as highly promising option (Vittal et al., 2002) because it had recorded the SYI value in the range of 0.50-0.58). Chhata soil series produced highest yield of sugarcane while Simri and Garhsauli series registered high B: $\mathrm{C}$ ratio and SYI. High yield was due to favourable soil and climatic conditions as well as good irrigation facilities while, high $\mathrm{B}$ : $\mathrm{C}$ ratio was registered on account of high prices of the produce, good market access and relatively high yield and less cost of cultivation. Singh et al., (1990) reported SYI values for different crops which vary from 1 to +1 ; high values indicated little deviation in yield over the period of time. Any practice yielding SI greater than 0.66 is considered as a recommendable component for production of a crop and SI of 0.50 to 0.65 is considered as highly promising, while a practice with SI less than 0.33 is undependable (Vittal et al., 2002). Based on SYI values it is concluded that rice, wheat, mustard, pearl millet and sugarcane are the recommendable option while, cotton is considered as highly promising option for the area (Table 2).

Currently, agriculture is facing several challenges viz., declining productivity of land resources, poor soil health, pressure to produce more from cultivated land, high cost of cultivation and low income, which in turn affected the livelihood of millions of farmers. The issue of livelihood security could aptly be addressed by adoption of viable strategies such as development of alternate land use options. To develop such viable options it is imperative to identify, assess and evaluate the constraints and potentials of natural bio-physical resources as well as socio-economic profile of the study area. During the course of study similar line of action was followed to study the variation in the above parameters within and among soil series to find out the opportunities for better livelihood through agricultural land use plan. Assessment of biophysical and socio-economic data is necessary to link social factors to broadscale change in land use patterns (Rudel, 2008; Verburg et al., 2004). Evaluation of biophysical, ecological and socio-economic parameters of an area is necessary for land suitability (FAO, 1976) and these factors affect the agricultural land use (Olaniyi et al., 2015). Biophysical parameters are significance because of their relative stability over time (Dent and Young, 1981; Triantafilis et al., 2001).

The developed alternate land use options took into consideration bio-physical and socio-economic information of the area, the yield and market values of the major crops (in terms of $\mathrm{B}$ : $\mathrm{C}$ ratio and $\mathrm{SYI}$ ) for assessing the economic viability and sustainability of the land use options towards ensuring livelihood security. Based on such parameters, crops, animal husbandry, horticulture and agroforestry (farm forestry) options were developed for the area. Martin et al., (1999) suggested farm forestry in and around crop fields. Above activities were considered as an alternate for the area based on soil and climatic conditions as well as market opportunities available.

The importance of agriculture in Indian economy is well known as it is vital to the sustenance and livelihood security of 
millions of marginal and small farmers. Under present day conditions of limited land resources farmers faced many problems in securing livelihood due to low yield and income from agriculture. The change in occupational structure in rural areas led to declining share of young age persons in farming activities particularly due to their participation in non-agricultural activities. However, agriculture is still major contributor to the livelihood earning. Women also contributed as much significantly as their male counterparts in livelihood earning activities. The shift in cropping pattern, change in land use and socio-economic fabric of the farming community calls for development of sustainable land use strategies to secure livelihood opportunity. In order to achieve diverse benefits from the natural resource base of the area, alternate land use options need to be developed which, inter alia proved to be economically viable and sustainable for different soil series and socio-economic conditions. Besides being able to ensure livelihood security for the rural households, it should also provide food, feed and fodder security through diverse sources (crops, livestocks, fruits and vegetables). Therefore, development of alternate land use options on scientific basis at local level is the need of the hour as it gaining currency from the researchers, scientists, policymakers and local stakeholders across the world to ensure food and livelihood security of the millions and millions of marginal and small farmers.

\section{Acknowledgement}

Authors express thanks to the Director, ICAR-NBSS\&LUP, Nagpur, India, for financial support and the respondent farmers of Chhata tehsil for sharing their information for the study.

\section{References}

Census of India, 2011. Ministry of home affairs, Government of India.

Chen, M., 1989. Women and household livelihood systems. ARDA 15, 2-3.

Costales, A.C., Pica-Ciamarra, U., and Otte, J., 2007. Livestock in a changing landscape: social consequences for mixed crop livestock production systems in developing countries. Propoor livestock policy initiative- A living from livestock. Research Report. Ref: 07-05: Feb, 2007. PPLPI.

Dent, D., and Young, A., 1981. Soil survey and land evaluation. George Allen and Uniwin: Boston. FAO (1976) a framework for land evaluation. FAO Soils Bulletin 32, Rome

Economic survey, 2015. Ministry of finance, Government of India.

FAO, 1976. A framework for land evaluation. Soils Bulletin 32. Food and Agriculture Organization of the United Nations, Rome

Geist, H.J., and Lambin, E.F., 2004. Dynamic causal patterns of desertification. Bio Science 54:9. doi: 10.1641/0006-3568

Haggblade, S., Hazell, P., and Brown, J., 1989. Farm-nonfarm linkages in rural sub Saharan Africa. World Development17 (8): 1173-1201.

Kumar, A., Mahapatra, S.K., Lal, T., Sidhu, G.S., and Singh, S.K., 2015. Alternate land use options for sustainable crop production. Abstract published in National Seminar on Sustainable Management of Land Resources for Land Resources for Livelihood Security held at NBSS\&LUP, Nagpur during January 28-30, 2015. p.167.

Martin, A., Sipho, S., and Stephen, T., 1999. Land tenure reform and rural livelihoods in Southern Africa. Overseas Development Institute. 
Natural resources perspectives 39: February, 1999

Mahapatra, S.K., Surya, N. J., Sidhu, G.S., Lal, T., Sharma, J.P., and Sharma, R.D. (2010). Characterization and classification of the soils of Mathura district of Uttar Pradesh for optimizing land use. Abstract published in National Seminar on Issues in Land Resource Management: Land Degradation, Climate change and Land Use Diversification held at NBSS\&LUP, Nagpur during October, 8-10th, 2010. Pp 64-65.

Mahapatra, S.K., Surya, J.N., Lal, T. and Sidhu, G.S., 2013. Soil resource based land use planning of Mathura district of Uttar Pradesh for sustainable agriculture production. Published in the proceedings of the $100^{\text {th }}$ session of Indian Science Congress. pp 279280.

Mishra, S., 2008. Risks, farmers' suicides and agrarian crisis in India: is there a way out? Indian Journal of Agricultural Economics 63(1): Jan.March, 2008

Olaniyi, A.O., Ajiboye, A.J., Abdullah, A. M., Ramli, M.F., and Sood, A.M., 2015. Agricultural land use suitability assessment in Malaysia. Bulgarian Journal of Agricultural Sciences 21(3): 560-572.

Pal, M.S., 2001. Women in Bangladesh: Country briefing paper. Asian Development Bank. Manila

Reardon, T., 1997. Using evidence of household income diversification to inform study of the rural nonfarm labor market in Africa. World Development 25(5): 735-748.

Reynolds, J.F., Stafford Smith, D.M., Lambin, E.F., Turner, B.L. II., Mortimore, M., Batterbury, S.P.J., Downing, T.E., Dowlatabadi, H., Ferna'ndez, R.J., Herrick, J.E., Huber-
Sannwald, E., Jiang, H., Leemans, R., Lynam, T., Maestre, F.T., Ayarza, M., and Walker, B., 2007. Global desertification: building a science for dryland development. Science 316:847. doi:10.1126/science.1131634

Rudel, T.K., 2008. Meta-analyses of case studies: a method for studying regional and global environmental change. Global Environment Change 18(1):1825. doi:10.1016/j.gloenvcha.2007.06.001

Safriel, U., and Adeel, Z., 2008. Development paths of drylands: thresholds and sustainability. Sustainability Science 3:117-123. doi:10.1007/s11625-007-0038-5

Safriel, U., Adeel, Z., Niemeijer, D., Puigdefabres, J., White, R., Lal, R., Winslow, M., Ziedler, J., Prince, S., Archer, E., and King, C., 2005. Dryland systems. In: Hassan R, Scholes R, Ash N (eds) Ecosystems and human well-being: current state and trends, Island Press, Washington, $1: 623-662$.

Sajjad, Z., 1989. Wage and labour market in agriculture: some comments. Bangladesh Institute of Development Studies 17(4): 83-91.

Semwal, R.L., Maikhuri, R.K., and Rao, K.S., 2001. Agriculture-ecology, practices and productivity. Garhwal Himalaya, nature, culture and society. (Eds., Kandari, O.P., and Gosain, O.P.) Trans Meda, Media House Srinagar Garhwal.

Singh, R.P., Das, S.K., Bhaskara Rao, U.M., and Narayana Reddy, M., 1990. Towards sustainable dryland agricultural practices- Bulletin published by CRIDA (Central Research Institute for Dryland Agriculture), Hyderabad.

Triantafilis, J., Ward, W.T., and McBratney, A.B., 2001. Land suitability 
assessment in the Namoi Valley of Australia, using a continuous model. Amsterdam Journal of Soil Research 39: 273-290.

Uma, H.R., Madhu, G.R., and Pushpa Nanaiah, K., 2013. Changing cropping pattern: a boon or a bane to food security? International Journal of Humanities and Social Science Invention. ISSN (Online): 2319- 7722, ISSN (Print): 2319-7714. www.ijhssi.org. 2(8): August, 2013. pp. 07-11.

Verburg, P.H., Schot, P., Dijst, M., and Veldkamp, A., 2004. Land use change modelling: current practice and research priorities. Geography Journal 61:309-324. doi: 10.1007/s10708-0044946-
Vittal, K.P.R., Maruthi Sankar, G.R., Singh, H.P., and Samra, J.S., 2002. Sustainability of practices of dryland agriculture: methodology and assessment. All India coordinated research project for dryland agriculture, central research institute for dryland agriculture, Indian council of agricultural research, Hyderabad 500 059. Pp.100.

Walingo, M.K., Liwenga, E.T., Kangalawe, R.Y.M., Madulu, N.F., and Kabumbuli, R., 2009. Perceived impact of land use changes and livelihood diversification strategies of communities in the Lake Victoria Basin of Kenya. Journal of Agricultural Biotechnology and Sustainable Development 1(3) pp 6978.

\section{How to cite this article:}

Ashok Kumar, S.K. Mahapatra, Tarsem Lal, R.P. Yadav and Singh, S.K. 2017. Alternate Land Use Options for Livelihood Security of the Farmers - A Case Study of Chhata tehsil, Mathura District, Uttar Pradesh, India. Int.J.Curr.Microbiol.App.Sci. 6(7): 279-295. doi: https://doi.org/10.20546/ijcmas.2017.607.033 